\title{
ROLE OF MICROORGANISMS IN THE PRODUCTION OF LIME MUD AND IMPLICATIONS FOR INTERPRETATION OF ANCIENT MICRITE DEPOSITS
}

ROBBINS*, L.L., Dept. of Geology, University of South Florida, 4202 E. Fowler Ave., Tampa, FL 33620; YATES, K., Dept. of Geology, University of South Florida, 4202 E. Fowler Ave., Tampa, FL 33620

Geologists have long been plagued by the lack of evidence for the origin of ancient micrite deposits: any paleontological evidence is typically obscured or lacking altogether. The role of modern marine picoplankton gives insight into the origin of one mode of lime mud formation and may aid in the interpretation of ancient marine deposits.

Whitings, patches of floating lime mud in supersaturated seawater on carbonate platforms, obtained from the Bahama Bank were analyzed utilizing biochemical techniques and Transmission Electron Microscopy. All Whitings indicated a close association between picoplankton cellular material and calcium carbonate crystals. Culture experiments indicated the presence of at least ten different picoplankton species in Whitings water. Two major genera found were the blue-green algae, Synechococcus and Synechocystis. Field and laboratory experimental data indicated that these cells and cellular organics play a major role in Whitings formation. The cells may undergo epicellular precipitation of calcium carbonate induced by photosynthesis. Environmental conditions necessary for this process have been delineated through field data and laboratory experiments.

While picoplankton organics are rarely preserved over geologic time, the product of their life habit, namely lime mud, is preserved as micrite. Thick occurrences of micrite deposited in marine environments are widespread throughout the geologic record, ranging in age from Precambrian to Recent. Although rare, fossilized blue-green algae have been observed in Archean rocks and may be the only evidence that implicates these organisms in lime mud formation. The Whitings phenomenon serves as an excellent example in which a specific type of organism may be a prolific contributor to the rock record, and yet leaves no direct paleontological evidence of its involvement. 